\title{
Chenopodium quinoa Willd. A new cash crop halophyte for saline regions of Egypt
}

\author{
Sayed S. Eisa ${ }^{1}$, M.A. Eid ${ }^{1}$, E.H. Abd El-Samad ${ }^{2}$, S.A. Hussin ${ }^{1}$, A.A. Abdel-Ati ${ }^{3}$, N.E. El-Bordeny ${ }^{1}$, S.H. \\ Ali $^{1}$, Hanan M.A. Al-Sayed ${ }^{1}$, M.E. Lotfy ${ }^{1}$, A.M. Masoud ${ }^{1}$, A.M. El-Naggar ${ }^{1}$ and M. Ebrahim $^{1}$ \\ ${ }^{1}$ Faculty of Agriculture, Ain Shams University, P.O. Box 68, Hadayek Shoubra, 11241, Shoubra El-Kheima, \\ Cairo, Egypt \\ ${ }^{2}$ Vegetable Crop Research Deptartment, Agricultural \& Biological Research Division, National Research Centre, \\ 33 El-Buhouth St., 12622, Dokki, Giza, Egypt \\ ${ }^{3}$ Plant Production Department, Ecology and Dry Land Agriculture Division, Desert Research Center, Cairo, \\ Egypt
}

\section{*Corresponding author: sayed_eisa@agr.asu.edu.eg, sayed_eisa@hotmail.com}

\begin{abstract}
A prerequisite for sustainable saline agriculture of cash crop halophytes in salt affected areas implies exact knowledge of their limits of salinity resistance. Hence, the first part of this study was carried out in pot experiment under greenhouse conditions to evaluate growth and seed yield of $C$. quinoa Willd. cv. Hualhuas to varying water salinity levels $(0,100,200,300,400$ and $500 \mathrm{mM} \mathrm{NaCl})$. The limit of salinity resistance was estimated at $200 \mathrm{mM} \mathrm{NaCl}\left(\sim 20 \mathrm{dSm}^{-1}\right)$ based on seed yield production. Depending on the results obtained from pot experiment, field trials were conducted in saline soil location (ECe $17.9 \mathrm{dSm}^{-1}$ ) and in non-saline soil location $\left(\right.$ ECe $\left.1.9 \mathrm{dSm}^{-1}\right)$. Seed yield significantly decreased under saline soil by about $61.7 \%$. Beside quantity, soil salinity led to reduce the percentage of moisture, total carbohydrate and total fat contents in seeds. Salinity did not significantly alter the protein content in quinoa seeds. Significant increases in the content of ash and fiber were detected in response to high soil salinity. The higher ash content in seeds under saline conditions was due to the increase of $\mathrm{Na}^{+}$as well as $\mathrm{K}^{+}, \mathrm{P}^{3-}$ and $\mathrm{Fe}^{++}$concentrations. By contrast, soil salinity led to significant decrease of $\mathrm{Ca}^{++}$and $\mathrm{Zn}^{++}$contents in seed. Energy dispersive $\mathrm{X}$-ray microanalysis showed that most of Na in the seeds produced at saline soil was mainly accumulated in the pericarp followed by embryo tissues, while, the interior reserving tissue (perisperm) exhibiting comparatively low concentration. Increasing most of essential minerals, especially Fe, in quino a seeds produced under high saline conditions given quinoa a distinctive value for human consumption. Quinoa can be grown and yielded successfully in salt-affected soils $\left(\right.$ ECe $17.9 \mathrm{dSm}^{-1}$ ), where, most if not all of traditional crops cannot grow, although the yield was reduced however, the seed quality was not highly affected.
\end{abstract}

Keywords: Quinoa; Salinity; Seed yield; Seed compositions; X-ray microanalysis.

\section{Introduction}

Despite the success of the green revolution, poverty and hunger remain major challenges in many areas of the world, particularly in developing countries where human populations are still rising. Continuous global expansion of population means that global demand for food, feed and fuel will increase and that leads to more intensive in use of land and water resources and thus accelerated land degradation and destruction of the environment (Godfray et al., 2010; Gonzalez et al., 2015). This situation might be more severe in developing countries. For example, the food balance in Egypt shows a drastic shortage and is far away from selfsufficiency. Increasing food production to meet the nutritional demand of vast growing population is a real challenge. This goal can only be realized by bringing new land under cultivation. Uncultivated land in Egypt desert occupied $96 \%$ of the total area and characterized with high evaporation (1500-2400 mm/year) and very low rainfall (5$200 \mathrm{~mm} / \mathrm{year}$ ). Parts of this desert are millions of hectares of coastal sites and salinized farmlands. Under such conditions, conventional crops misplace their advantages to reduce the gap between food production and consumption. In order to counteract the detrimental effects of salinity on conventional crops, intensive research has been conducted, worldwide, to increase salt tolerance using genetic manipulation (Flowers, 2004), but the outcomes remain not significant so far (Läuchli and Grattan, 2007). An alternative approach is studied to utilize the natural salt-tolerance halophytes for sustainable crop production, particularly for economic interests (food, fodder and fuel) or ecological reasons (soil desalinization, phytoremidation, dune fixation, $\mathrm{CO}_{2}$ sequestration) (Ashour et al., 1997; Leith and Mochtschenko, 2002; Reddy et al., 2008; Eid and Eisa, 2010; Koyro et al., 2011; Ladeiro, 2012; Hussin et al., 2013).

Chenopodium quinoa Willd. is a facultative halophyte belongs to family Amaranthaceae. This Andean grain is an important crop of the Andean region in South America from Colombia $\left(2^{\circ} \mathrm{N}\right)$ to central Chile $\left(40^{\circ} \mathrm{S}\right)$ (Risi and Galwey, 1984; Jacobsen et al., 2003). Quinoa has recently gained worldwide attention because of its ability to be reproductive under various stress conditions (Choukr-Allah et al., 2016). Quinoa as a halophytic species has the ability to cope with salinity levels as high as those present in sea water (Koyro 
and Eisa, 2008; Hariadi et al., 2011; Shabala et al., 2013; Panuccio et al., 2014). It is highly resistant to drought (Gonzalez et al., 2009a; Jacobsen et al., 2009; Gonzalez et al., 2011). Also, quinoa is well adapted to freezing temperature, wind and UV since it could be grown at an elevation of 3500-3900 m above the sea level (Jacobsen et al., 2003; Gonzalez et al., 2009b). Moreover, quinoa is frequently cultivated in Andean region where soil fertility is poor (Vilche et al., 2003). An additional reason for raising the attention of quinoa cultivation worldwide is its extraordinary nutritional value, as its grains have an excellent balance of carbohydrates, lipids and protein for human nutrition. In addition, the grains provide a rich source of a wide range of minerals (Ca, P, Mg, Fe and $\mathrm{Zn}$ ), vitamins (B1, B2, C and E), and natural antioxidants (Abugoch et al., 2009; Koyro and Eisa 2008). Quinoa grains contain a protein of outstanding quality, better balanced in terms of amino acids composition than that of most cereals (Tapia, 2000). Furthermore, the proportions of all essential amino acid exceed those recommended by FAO and WHO in all age-group categories (Risi and Galwey, 1984; Wright et al., 2002; Repo-Carrasco et al., 2003). The food and Agricultural Organization (FAO) reported that quinoa is closer to the ideal protein balance than any grains being at least equal to milk in protein quality (Pappier et al., 2008).

Therefore, quinoa as a facultative halophyte with exceptional nutritional quality could be a promising candidate of cash crop halophytes to increase the economic value of poor saline areas in arid and semi-arid regions of southern coast of the Mediterranean Sea. However, the limit of salinity tolerance of quinoa is varied between ecotypes and cultivars (Adolf et al., 2012; Bonales-Alatorre et al., 2013). In general, varieties originating from salt affected area are more adapted to saline condition than those from non-saline area (Shabala et al., 2013). For example, due to the widespread of salinization in Peru 250,000 ha out of 800,000 ha irrigated in the coastal region are saline, the Peru-native quinoa is thought to be more tolerant to salt stress (Jacobsen et al., 2001; Jacobsen et al., 2003; Gomez-Pando et al., 2010). Therefore, the present work was undertaken to evaluate the Peruvian cultivar Hualhuas under Egyptian conditions for potential seed yield and its quality as chemical compositions at coastal saline area (ECe $17.9 \mathrm{dsm}^{-1}$ ) compared with nonsaline soil $\left(\right.$ ECe $\left.1.9 \mathrm{ds} . \mathrm{m}^{-1}\right)$.

\section{Results}

Estimating the limit of salinity resistance in quinoa $c v$. Hualhuas under sand culture

Comparative growth response of quinoa plants and its different organs to various salinity levels $(0,100,200,300$, 400 and $500 \mathrm{mM} \mathrm{NaCl}$ ) after 6 weeks of treatment is illustrated in Figure (1 A \& B). Salinity negatively affected the growth and development of all plant organs and the variations between treatments were evident four weeks after exposure to salinity stress. Plant growth and biomass accumulation (expressed as fresh weight) were gradually and significantly $(\mathrm{P} \leq 0.05)$ reduced as $\mathrm{NaCl}$ salinity increased, the effect which was more pronounced at $500 \mathrm{mM} \mathrm{NaCl}$. Low water salinity $(100 \mathrm{mM} \mathrm{NaCl})$ resulted into significant $(\mathrm{P} \leq 0.05)$ reduction of about $35.8 \%$ in the total plant fresh weight relative to the control (Fig. $1 \mathrm{~B}$ ). The overall plant growth and biomass accumulation was notably reduced to roughly $50 \%$ at water salinity of about $300 \mathrm{mM} \mathrm{NaCl}$ (Fig. 1 B). Plants exposed to the highest water salinity level were clearly withered with shallow and very tiny root system, fewer numbers of branches and leaves and produced smaller and more compacted inflorescences. Their leaves were smaller, thicker, exhibiting a light green color, with visible symptoms of $\mathrm{Na}^{+}$and $\mathrm{Cl}^{-}$toxicity and/or nutrient disorders. However, salt-stressed plants were able to survive and could complete their life cycle even at the full strength water salinity $(500 \mathrm{mM} \mathrm{NaCl})$. The highest water salinity $(500 \mathrm{mM}$ $\mathrm{NaCl})$ resulted into considerable and significant $(P \leq 0.05)$ reductions of about $79.2,71.5,78.9$ and $85.3 \%$ in the total plant biomass, fresh weight of root, shoot and inflorescence, respectively, relative to the corresponding control (Fig.1 B).

\section{Field trials}

On average, the grain yield of $C$. quinoa plants reached $1151+52.7 \mathrm{~kg} \mathrm{ha}^{-1}$, while the weight of 1000 grains was $2.33 \pm 0.15$ under non-saline conditions (Table 3 ). The same trend of salt-induced reductions in yield attributes was also observed. Soil salinity markedly and significantly $(P \leq 0.05)$ lowered the grain yield and weight of 1000 grains by 62 and $26 \%$, respectively, relative to non-saline soils.

Beside quantity, soil salinity adversely influenced the grain quality. It led to reduce the percentage of moisture content, total carbohydrate and total fat contents by $12.2,4.8$ and $17.3 \%$, respectively, relative to the corresponding control. However, soil salinity did not significantly alter the protein content of quinoa grains, being about $13 \%$ (Table 3 ). Significant $(P \leq 0.05)$ increases of about 110.8 and $15.7 \%$ in the content of the ash and fiber, respectively, were observed in response to high soil salinity. As for mineral contents of the grains, high soil salinity led to about 4-folds increase in $\mathrm{Na}$ content compared to non-saline soils. This was accompanied by significant increases of about 30.5, 15.1 and $48.7 \%$ for $\mathrm{P}, \mathrm{K}$ and $\mathrm{Fe}$, respectively, relative to non-saline soil. By contrast, soil salinity induced obvious decreases of about 57.1 and $25.1 \%$ in the contents of $\mathrm{Ca}$ and $\mathrm{Zn}$, respectively, compared to non-saline soils. $\mathrm{Mn}$ and $\mathrm{Cu}$ contents were not significantly changed in response to the soil salinity (Table 3 ).

\section{Energy Dispersive X-ray microanalysis}

Distribution pattern of some essential elements (P, K, Mg and $\mathrm{Na}$ ) in various tissues of quinoa seed produced from both location saline (ECe $17.9 \mathrm{dSm}^{-1}$ ) and non-saline (ECe 1.9 $\mathrm{dSm}^{-1}$ ) soils was examined using Energy Dispersive X-ray microanalysis (Fig. 3). EDX-analysis clearly pointed out that $\mathrm{P}, \mathrm{K}$ and $\mathrm{Mg}$ were mainly located in embryo tissues (i.e. cotyledons and hypocotyl-radical axis), meanwhile their contents were very low in perisperm tissue. Examination by Scanning Electron Microscope showed an intensely accumulation of protein bodies in cotyledons (Fig. 4 A), and in hypocotyl-radical axis (Fig. $4 \mathrm{~B}$ ). It is well known that $\mathrm{P}$, $\mathrm{K}$ and $\mathrm{Mg}$ are component of the phytin globoid within protein bodies. Perisperm considered as a main storage tissue in quinoa seeds, it occupies the most of internal space of seed. Perisperm cells are full of starch grains which are angular in shape (Fig. 4 C \& D). Sodium was scarcely detected in various tissues of whole quinoa seeds produced under nonsaline soil conditions as shown in Figure 3. Soil salinity induced strongly changes on the distribution pattern of $\mathrm{Na}$ content in whole quinoa seeds. It led to increase Na contents within the different tissues, the highest accumulation of $\mathrm{Na}$ was observed in cover seed layers (pericarp and seed coat) followed by embryo tissues, but with comparatively low concentration in perisperm. Conspicuous higher amounts of $\mathrm{K}, \mathrm{Mg}$ and $\mathrm{P}$ were observed in the tissues of embryo (cotyledon and hypocotyl-radical axis) of the seeds produced under saline soils (Fig. 3). 
Table 1. Physical and chemical proprieties of soil samples collected from non-saline and saline locations.

\begin{tabular}{|c|c|c|}
\hline Parameters & Non-saline soil & Saline soil \\
\hline Sand $(\%)$ & 28.1 & 54.4 \\
\hline Silty $(\%)$ & 38.6 & 36.5 \\
\hline Clay (\%) & 33.3 & 9.1 \\
\hline Soil texture & Clay Loam & Sandy Loam \\
\hline Balk density $\mathrm{gcm}^{-3}$ & 1.50 & 1.79 \\
\hline Saturation $(\%)$ & 55 & 75 \\
\hline Organic matter (\%) & 1.51 & 0.53 \\
\hline $\mathrm{CaCO}_{3}(\%)$ & 1.72 & 9.63 \\
\hline $\mathrm{pH}$ (soil paste) & 7.46 & 8.70 \\
\hline $\operatorname{ECe}\left(\mathrm{dSm}^{-1}\right)$ & 1.9 & 17.9 \\
\hline Soluble $\mathrm{Na}^{+}$meq $\mathrm{l}^{-1}$ & 6.4 & 105 \\
\hline Soluble $\mathrm{K}^{+}$meq $^{-1}$ & 1.4 & 5.7 \\
\hline Soluble $\mathrm{Ca}^{++}$meq $\mathrm{l}^{-1}$ & 7.2 & 32.9 \\
\hline Soluble $\mathrm{Mg}^{++}$meq $\mathrm{l}^{-1}$ & 4.1 & 46.7 \\
\hline Soluble $\mathrm{Cl}^{-}$meq $\mathrm{l}^{-1}$ & 9.0 & 140.3 \\
\hline Soluble $\mathrm{HCO}_{3}^{-}$meq $\mathrm{l}^{-1}$ & 3.8 & 1.4 \\
\hline Soluble $\mathrm{CO}_{3}=$ meq l$^{-1}$ & 0.0 & 0.0 \\
\hline Soluble $\mathrm{SO}_{4}=\mathrm{meq} \mathrm{l}^{-1}$ & 6.7 & 42.3 \\
\hline Available Fe mg kg-1 & 4.6 & 6.1 \\
\hline Available Mn mg kg-1 & 6.9 & 2.5 \\
\hline Available $\mathrm{Zn} \mathrm{mg} \mathrm{kg}$ & 1.6 & 0.9 \\
\hline
\end{tabular}
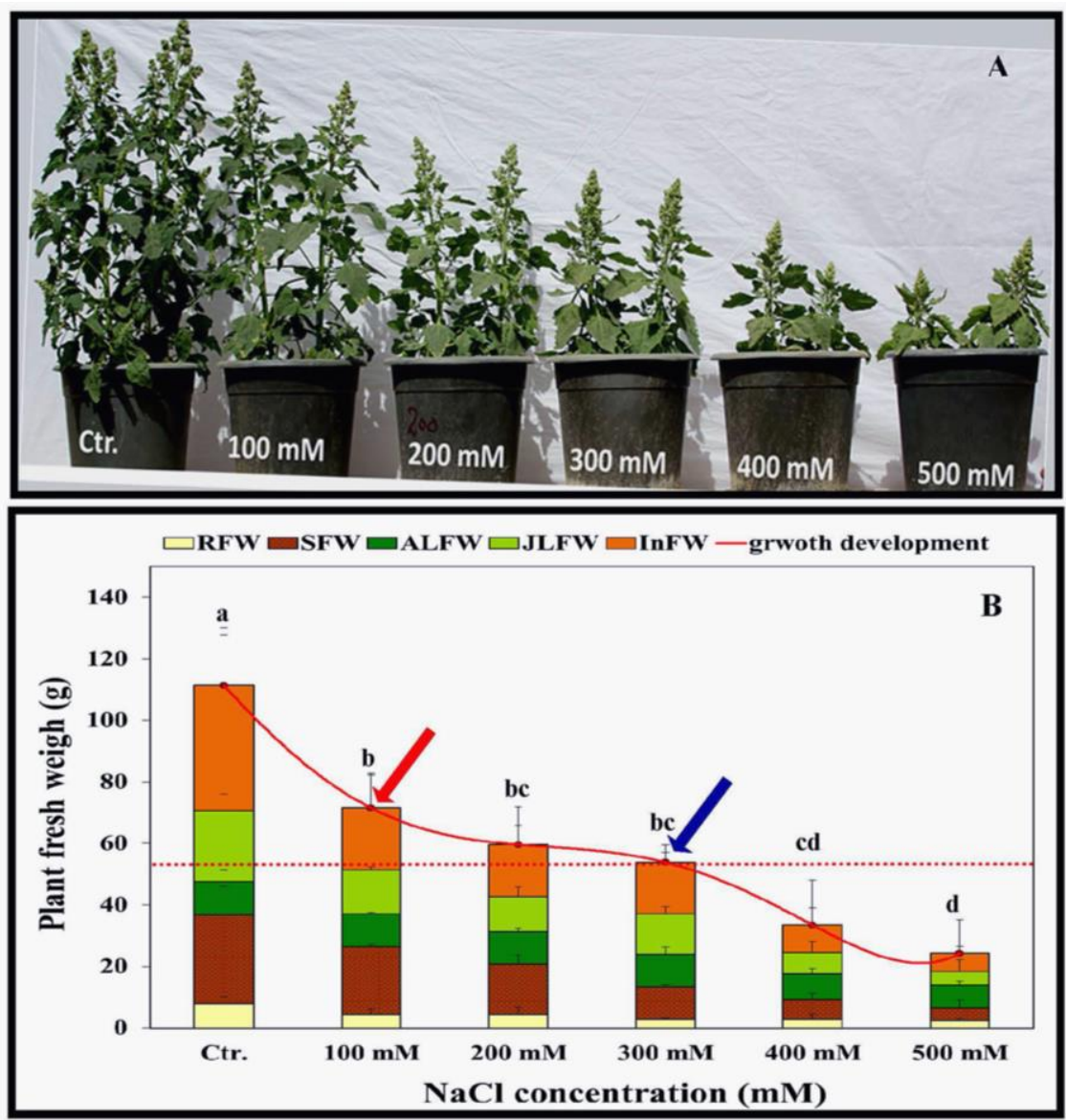

Fig 1. Growth and development of quinoa plant cv. Hualhuas (A) and responses of different plant organs (B) to different $\mathrm{NaCl}$ salinity levels after 6 weeks of salinity treatments, expressed as plant fresh weight (FW).The initial significant reduction in plant fresh weight indicates the threshold salinity level (red arrow). The dotted red line marks the $\mathrm{C}_{50}$ values. The crossover of the dotted and solid red lines reflects the salt concentration where the growth depression falls down to $50 \%$ of the control plant (the limits of salinity resistance, blue arrow). R, root; S, stem; AL, adult leaves; JL, juvenile leaves; In, inflorescence. Each column represents the mean of six replicates, the bars represent standard errors and bars with the same letter are not significantly different at $\mathrm{P} \leq 0.05$. 
Table 2. Some chemical proprieties of irrigation water collected from non-saline and saline locations.

\begin{tabular}{|c|c|c|}
\hline Parameters & $\begin{array}{c}\text { Non-saline soil } \\
\text { location }\end{array}$ & $\begin{array}{c}\text { Saline soil } \\
\text { location }\end{array}$ \\
\hline $\mathrm{pH}$ & 7.1 & 7.95 \\
\hline $\mathrm{EC} \mathrm{dSm}{ }^{-1}$ & 0.43 & 1.56 \\
\hline $\mathrm{Na}^{+}$meq $1^{-1}$ & 1.4 & 11.8 \\
\hline $\mathrm{K}^{+}$meq $^{-1}$ & 0.2 & 0.3 \\
\hline $\mathrm{Ca}^{++} \mathrm{meq}^{-1}$ & 1.0 & 2.4 \\
\hline $\mathrm{Mg}^{++}$meq $\mathrm{l}^{-1}$ & $\begin{array}{l}1.0 \\
1.2\end{array}$ & $\begin{array}{l}2.4 \\
3.5\end{array}$ \\
\hline $\mathrm{Cl}^{-} \mathrm{meq} \mathrm{l}^{-1}$ & $\begin{array}{l}1.2 \\
1.2\end{array}$ & $\begin{array}{l}5.5 \\
8.6\end{array}$ \\
\hline $\mathrm{HCO}_{3}^{-}$meq $\mathrm{l}^{-1}$ & 0.6 & 3.6 \\
\hline $\mathrm{CO}_{3}={ }^{=} \mathrm{meq}^{-1}$ & 0.0 & 0.0 \\
\hline $\mathrm{SO}_{4}=\mathrm{meq} \mathrm{l}^{-1}$ & 2.0 & 6.1 \\
\hline
\end{tabular}

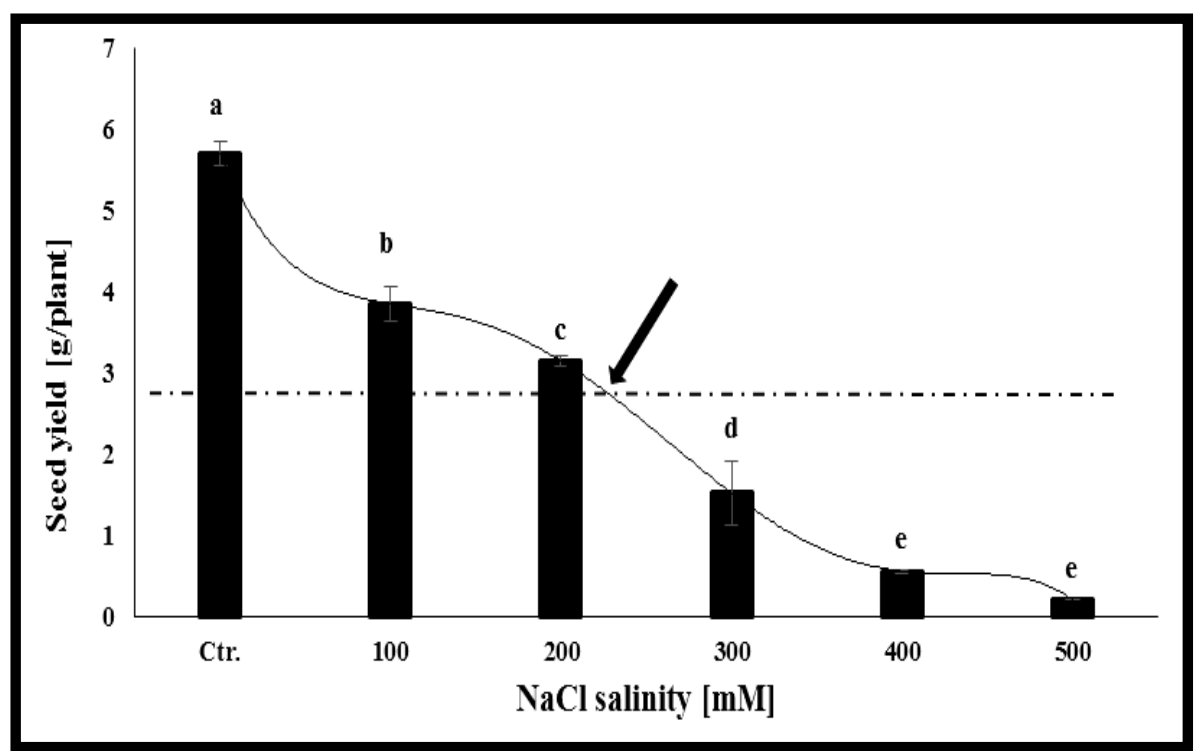

Fig 2. Seed yield responses to different $\mathrm{NaCl}$ salinity levels after 9 weeks of salinity treatments. The dotted line marks the $\mathrm{C}_{50}$ value, while arrow shows the limited of salinity resistance. Each column represents the mean of six replicates, the bars represent standard errors and bars with the same letter are not significantly different at $P \leq 0.05$.

Table 3. Quinoa seed yield, weight of 1000 seeds, some chemical composition and nutrient contents of grains harvested from nonsaline and saline soils.

\begin{tabular}{lcc}
\hline Parameters & Non-saline soil & Saline soil \\
\hline Grain yield $\left(\mathrm{kg} \mathrm{ha}^{-1}\right)$ & $1151 \pm 52.7^{\mathrm{a}}$ & $441 \pm 5.2^{\mathrm{b}}$ \\
Weight of $1000 \mathrm{seeds}^{\mathrm{a}}(\mathrm{g})$ & $2.33 \pm 0.15^{\mathrm{a}}$ & $1.67 \pm 0.12^{\mathrm{b}}$ \\
Moisture $(\%)$ & $8.19 \pm 0.39^{\mathrm{a}}$ & $7.20 \pm 0.33^{\mathrm{b}}$ \\
Proteins $(\%)$ & $13.03 \pm 0.88^{\mathrm{a}}$ & $13.45 \pm 0.17^{\mathrm{a}}$ \\
Ash $(\%)$ & $3.68 \pm 0.24^{\mathrm{b}}$ & $7.79 \pm 0.29^{\mathrm{a}}$ \\
Fat $(\%)$ & $5.21 \pm 0.45^{\mathrm{a}}$ & $4.270 \pm 0.36^{\mathrm{b}}$ \\
Fiber $(\%)$ & $3.80 \pm 0.32^{\mathrm{b}}$ & $4.39 \pm 0.25^{\mathrm{a}}$ \\
Carbohydrate $(\%)$ & $66.09 \pm 1.41^{\mathrm{a}}$ & $62.91 \pm 0.98^{\mathrm{b}}$ \\
Phosphorus $\left(\mathrm{g} \mathrm{kg}^{-1}\right)$ & $3.67 \pm 0.23^{\mathrm{b}}$ & $4.83 \pm 1.10^{\mathrm{a}}$ \\
Potassium $\left(\mathrm{g} \mathrm{kg}^{-1}\right)$ & $8.80 \pm 1.56^{\mathrm{b}}$ & $10.13 \pm 1.93^{\mathrm{a}}$ \\
Calcium $\left(\mathrm{g} \mathrm{kg}^{-1}\right)$ & $2.83 \pm 0.15^{\mathrm{a}}$ & $1.21 \pm 0.10^{\mathrm{b}}$ \\
$\mathrm{Mn} \mathrm{mg} \mathrm{kg}^{-1}$ & $28.67 \pm 7.37^{\mathrm{a}}$ & $27.76 \pm 2.52^{\mathrm{a}}$ \\
$\mathrm{Zn} \mathrm{mg} \mathrm{kg}^{-1}$ & $22.67 \pm 4.04^{\mathrm{a}}$ & $17.03 \pm 6.56^{\mathrm{b}}$ \\
Fe mg kg & $109.00 \pm 21.4^{\mathrm{a}}$ \\
$\mathrm{Na} \mathrm{mg} \mathrm{kg}^{-1}$ & $73.33 \pm 13.3^{\mathrm{b}}$ & $274.67 \pm 49.0^{\mathrm{a}}$ \\
Cu mg kg & & $4.97 \pm 1.11^{\mathrm{a}}$ \\
\hline Means within a column followed by the same letter are not signific antly different at $P \leq 0.05$ as determined by Duncan test.
\end{tabular}




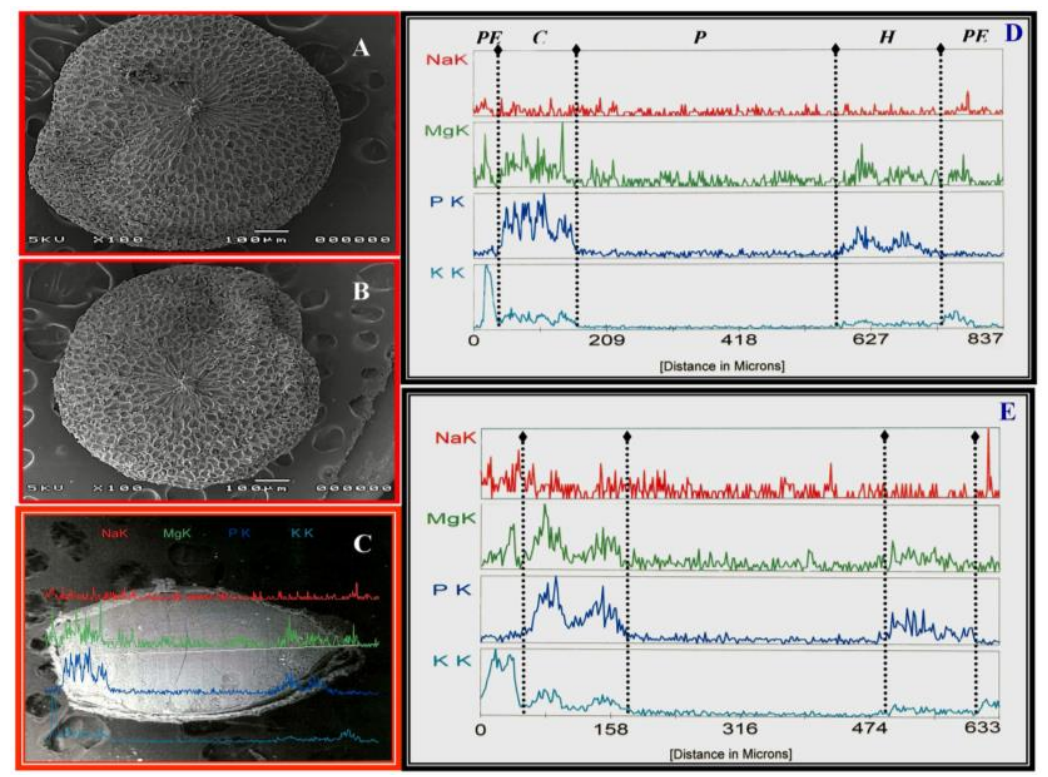

Fig 3. Scanning electron micrographs showing the effect of non-saline (A) and saline (B) conditions on quinoa grain filling and size. EDX-line scanning technique (C) displaying the distribution pattern of $\mathrm{Na}, \mathrm{Mg}, \mathrm{P}$, and $\mathrm{K}$ in different seed tissues produced from nonsaline (D) and saline soil (E). PE, Pericarp; C, cotyledon; P, priesperm; H, hypocotyl-radical axis.

\section{Discussion}

Sustainable growth of quinoa on saline soil presupposes initially the exact knowledge of the limits of salinity resistance (Koyro et al., 2008). The limit of salinity tolerance is defined physiologically as the $\mathrm{NaCl}$ salinity at which the yield of a crop under saline conditions relative to its yield under non-saline conditions reaches less than 50\% (Kinzel, 1982). Therefore, the limit of salt resistance can be easily detected at the growth development of halophytes at different salinities. In the present work, the effect of six salinity levels $(0,100,200,300,400$ and $500 \mathrm{mM} \mathrm{NaCl})$ on growth and yield of $C$. quinoa cv. Hualhuas was studied in sandy culture pot experiment. The results obtained clearly indicated that the growth of quinoa was considerably decreased with increasing $\mathrm{NaCl}$ salinity level. The initial significant reduction (threshold salinity tolerance) for both of biomass and seed

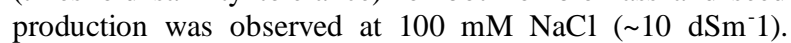
Meanwhile, the limit of salinity resistance $\left(\mathrm{C}_{50}\right.$ value $)$ for biomass growth was estimated at $300 \mathrm{mM} \mathrm{NaCl}\left(\sim 30 \mathrm{dSm}^{-1}\right)$ and for seed yield at around $220 \mathrm{mM} \mathrm{NaCl}\left(\sim 22 \mathrm{dSm}^{-1}\right)$ as shown in Figure 2. Similar result was found by Hariadi et al. (2011) who mentioned that, the optimal plant growth of quinoa has been at $\mathrm{NaCl}$ concentration of $100-200 \mathrm{mM}$ (10$20 \mathrm{dSm}^{-1}$ ). The results obtained from Koyro and Eisa (2008) indicated the initial significant reduction in growth development for Peruvian cultivar Hualhuas grown under hydroponic technique at $200 \mathrm{mM} \mathrm{NaCl}$ and the limit of salt resistance at $300 \mathrm{mM} \mathrm{NaCl}$. On the other hand, loss $50 \%$ of seed yield, in the pot experiments of the present study, was observed at around $\sim 20 \mathrm{dSm}^{-1}$ compared to control. Meanwhile, the reduction of the seed yield in the field trials was reached to $61.7 \%$ at similar level of salinity in soil $(\sim 20$ $\left.\mathrm{dSm}^{-1}\right)$ less than that of non-saline soil. This severely reduction $(12 \%)$ under saline field conditions compared with pot experiments was probably associated with physical and chemical constraints of the soil under saline field conditions. In this respect, Karyotis et al. (2003) indicated that the considerable seed yield loss under saline soil condition $(6.5$ $\mathrm{dSm}^{-1}$ ) was due to poor and uneven plant density caused by adverse soil properties such as high soil $\mathrm{pH}(\mathrm{pH} 8.5)$ and poor aeration and water permeability. However, yield loss due to salinity stress is closely related to four major constraints: (1)
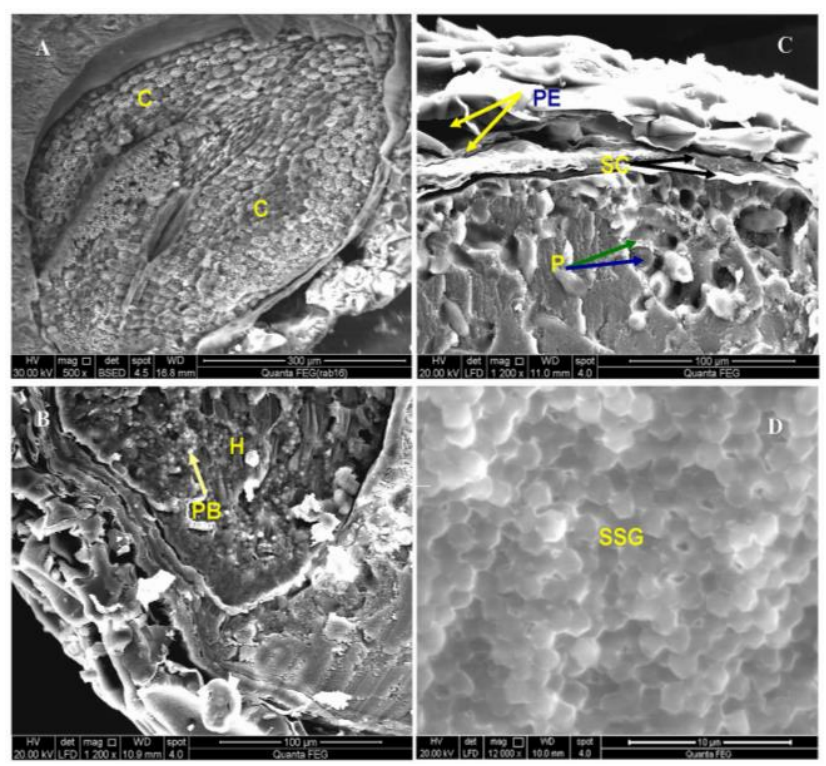

Fig 4. Scanning electron micrographs of cross section of quinoa seed. A. cross section in cytolodons (C); B. cross section in Hypocotel-radical axis $(\mathrm{H})$ showing protein bodies (PB); C. pericarp (PE) consists of two layers (yellow arrows). Seed coat (SC) has two layers (black arrows). Perisperm (P) full of starch grains, which are distributed in the forms of single starch granules (SSG, green arrow) and compound starch granules (CSG, blue arrow); D. cross section in perisperm showing single starch grains (SSG).

water deficit, (2) ion toxicity, (3) nutrient imbalance, (4) restriction of $\mathrm{CO}_{2}$ uptake (Marschner, 1995; Stavridou et al., 2016; Munns and Tester, 2008). Concerning the effect of salinity on quinoa plants, Eisa et al., (2012), reported that neither osmotic stress nor ion deficiency or toxicity appears to be determinant for $C$. quinoa under saline condition. Salt induced growth reduction of quinoa plants is presumably due to low photosynthesis supply as a consequence of impaired photosynthetic capacity. Reduced photosynthesis and lower activity of starch synthesis towards grain filling, coupled with reduced pollen viability leading to a reduction of seed set and 
lower grown yield of rice plants under saline conditions (Khatum and Flowers, 1995; Sultana et al., 1999; Khan and Abdullah 2003).

Beside quantity, the chemical compositions of quinoa seeds were also changed under saline soil cultivation. Starch reserves are mainly found in the perisperm, while proteins, lipids, and minerals reserves are located mostly in the embryo and endosperm. Phytin globoid crystals are found inside protein bodies in cells of endosperm and embryo tissues (Prego et al., 1998). In the present study, soil salinity did not significantly influence on protein content of Peruvian cultivar Hualhuas. Similar trend obtained by $\mathrm{Wu}$ et al. (2016) who reported that increasing $\mathrm{NaCl}$ concentrations up to $32 \mathrm{dSm}^{-1}$ did not alter protein content in quinoa seeds. In this regard, Koyro and Eisa (2008) mentioned that the lower C/N ratio at high saline levels $(>300 \mathrm{mM} \mathrm{NaCl})$ was a reasonable explanation of an increase in protein content, accompanied with a reduction in total carbohydrate. This was agree with the results obtained by Burrieza et al. (2011) who reported a higher dehydrin accumulation in the embryos of $C$. quinoa Hualhuas cultivar under high salinity stress compared to control, and suggested that may allow the species to achieve the establishment of new cultivation (in the initial stages of the next generation) under extreme environment conditions. However, salt induced change in protein content, may be by increasing of protein content in salt resistant species or vice versa in salt sensitive ones (Abdullah et al., 2001; AlAghabary et al., 2004; Kalifa et al., 2004; Mishra and Das, 2004).

The content of carbohydrates was significantly lower in seeds of quinoa produced at saline-soil than those grown in non-saline soil (Table 3). One of possible explanation of this reduction could be that most defense mechanisms are energy consuming and changes the balance among anabolism, catabolism and storage. In this respect, Abdullah et al. (2001) observed that starch synthetase activity in developing grains was significantly inhibited under salinity stress. Similar to carbohydrates content, total lipids in seeds was significantly decreased at saline-soil. In this concern little is known about salt-induced changes of oil content and fatty acid composition in the seeds of quinoa. Brazkez et al. (2016) reported that the lipid content in quinoa seeds increased from $6.57 \%$ in control to $7.98 \%$ in $125 \mathrm{mM} \mathrm{NaCl}$ treatment; however, there was no significant difference between treatments. Similar trend was reported by Pulvento et al. (2012) who found that salinity conditions had no effect on lipid content of "Titicaca" grains, which they estimated to range between 5.7 and $5.8 \%$. In contrast to quinoa, sunflower plants illustrated a seed oil yield reduction of $5 \%$ per unit increase in EC above $4.8 \mathrm{dSm}^{-1}$ (Francois, 1996). However, Yeilaghi et al. (2012) mentioned that the reduction of oil content in safflower seeds was greatly varied among genotypes due to salt-stress, whereas the salt tolerant of safflower genotypes were less affected by salinity than saltsensitive ones.

The distribution of minerals in seeds of quinoa grown under saline-soil seems to be highly regulated. In spite of increasing $\mathrm{Na}$ concentration by around four folds in grains at saline-soil but, concentrations of $\mathrm{K}, \mathrm{P}$ and $\mathrm{Fe}$ were significantly higher in seeds at saline-soil than those of nonsaline soil. A Higher accumulation of some essential needed elements ( $\mathrm{P}, \mathrm{K}$ and $\mathrm{Fe}$ ) or even stable contents of Mn under high salinity conditions may be one of salinity tolerance mechanisms and also, it gives quinoa seeds, produced from saline agriculture, a higher economic value for human consumption. A clear evidence of high selectivity mechanism in quinoa seeds, under salt stress, has been identified by
Energy Dispersive X-ray microanalysis (Fig. 3). Quinoa cultivar Hualhuas has the ability to accumulate the excessive $\mathrm{Na}$ in pericarp and seed coat layers followed by lower amount in embryo tissues, while the interior storage tissue (perisperm) showed comparatively low $\mathrm{Na}$ content. This exclusion of $\mathrm{Na}$ in the quinoa seed interior has been reported by Koyro and Eisa (2008), who given an overall picture of higher selectivity mechanism. Moreover, our results indicated that increases on content of $\mathrm{Na}$ in embryo tissues were accompanied by obvious increases on contents of $\mathrm{K}, \mathrm{P}$ and $\mathrm{Mg}$ as a response to soil salinity. This is may be a clear evidence of distinctive abilities of quinoa to regulate distribution of osmoregulation inorganic ions primarily $\mathrm{K}$ and $\mathrm{Na}$ in in pericarp and embryo tissues, thus allows seeds to germinate under high saline conditions. In this respect, Prado et al. (2000) reported that the germination of quinoa seeds taken from salt treated plants was accelerated significantly in comparison with control. It is possible that high $\mathrm{Na}$ and $\mathrm{K}$ concentrations in pericarp can have direct effects on accelerated germination of quinoa grains by decreasing the water potential in the wall of the plant ovary.

\section{Materials and Methods}

\section{Pot experiment}

As has been reported before (Koyro et al., 2006; Hussin et al., 2013), a prerequisite for the sustainable utilization of a new non-conventional crop using alternative (saline) water sources on marginal lands is detailed knowledge about the level of salt resistance on one hand and the individual mechanisms conferring salt resistance on the other hand. Hence, the first part of this study aimed to evaluate the growth, development and performance of $C$. quinoa Willd. $\mathrm{cv}$. Hualhuas to varying water salinity levels under artificial conditions in the greenhouse using sandy culture quick check system (QCS), modified after Koyro (2003). To achieve that, pot experiments were conducted in the greenhouse of Agricultural Botany Dept., Faculty of Agriculture, Ain Shams University (latitude $30^{\circ} 06^{\prime} 48^{\prime \prime}$ and longitude $\left.31^{\circ} 14^{\prime} 52^{\prime \prime}\right)$ during the growing seasons 2011 and 2012. Seeds of $C$. quinoa Willd. cv. Hualhuas [origin: International Potato Center (CIP), Lima, Peru] were surface sterilized before sowing with ethanol $70 \%$ for $10 \mathrm{sec}$, then with sodium hydrochloride solution (5\% active chloride) for 10 minutes. The seeds were then washed thoroughly with distilled water several times and air-dried. They were then sown into black plastic pots $(20 \mathrm{~cm}$ diameters with bottom drainage holes), each filled with $8 \mathrm{~kg}$ of washed sand (10 seeds per pot). Filter paper $(9 \mathrm{~cm}$ diameter) was placed in the bottom of each pot to avoid leak of sand from drainage holes. The pots $(\mathrm{N}=72$ pots) were kept on a bench in the greenhouse under conditions of photoperiodic (10.4 h light/13.6 h dark), ambient temperature of $28 \pm 2^{\circ} \mathrm{C}$ daytime and $16 \pm 2^{\circ} \mathrm{C}$ night time, relative humidity of $50-70 \%$, and light intensity was in the range of $1500-2000 \mu \mathrm{mol} \mathrm{m} \mathrm{s}^{-2}$ at the plant level. One week after germination, the pots were irrigated manually and regularly with Hogland nutrient solution (Arnon and Hogland, 1940) when the soil moisture reached $60-70 \%$ of the water holding capacity. After the emergence of the first two true leaves, the plants were thinned to two seedlings of uniform size per pot. Salinity treatments were started four weeks after sowing date. The pots were divided into six groups, each with six replicates, and $\mathrm{NaCl}$ concentration was raised gradually in the nutrient solution in steps of $100 \mathrm{mM}$ $\mathrm{NaCl}$ daily until the final concentration was reached to avoid salt shock injuries. There were altogether six salinity 
treatments i.e. control, 100, 200, 300, 400 and $500 \mathrm{mM} \mathrm{NaCl}$; equivalent to $0,20,40,60,80$ and $100 \%$ of seawater salinity (sws). The biomass productions were harvested at six weeks after the initiation of salinity treatments. Plant samples were destructively harvested and separated into roots (R), stems (S), adult leaves (AL), juvenile leaves (JL) and inflorescences (In). Meanwhile, seeds were harvested after 9 weeks from salinity treatments. The fresh weights of all plant organs were directly captured. The level of salt resistance in C. quinoa plants was adequately measured on the basis of two parameters according to Shannon and Grieve (1999); (i) salinity resistance threshold (salinity level that causes the initial significant reduction in the maximum expected growth or yield) and (ii) the $\mathrm{C}_{50}$ value (salinity level leads to reduce the maximum mass production or yield by $50 \%$ ).

\section{Field experiments}

Although eco-physiological studies under environmentalcontrolled conditions have the potential to provide highly valuable means of detecting the level of salt resistance and the individual mechanisms of species against $\mathrm{NaCl}$ stress, it is only the first step for developing a non-conventional cash crop. Designing of a sustainable production system in plantations for a forward-looking risk assessment of saline irrigation at local substrates and climatic conditions is crucial, since several responses underlying salt resistance may be overlooked when operating outside the field context. Therefore, field trail experiments were conducted to evaluate the growth and performance of quinoa in two different local locations. The first location (L1) was characterized by high saline soil (ECe $17.9 \mathrm{dSm}^{-1}$ Typic Aquisalids) and located in northwestern part of Sinai (latitude $32^{\circ} 28^{\prime} 44^{\prime \prime}$ and longitude $\left.31^{\circ} 56^{\prime} 35^{\prime \prime}\right)$. The other location (L2) was characterized by non-saline soil (ECe $1.9 \mathrm{dSm}^{-1}$ Typic Torrifluvents) and located in north Cairo at the experimental station of the Faculty of Agriculture, Ain Shams University (latitude $30^{\circ} 06^{\prime} 48^{\prime \prime}$ and longitude $\left.31^{\circ} 14^{\prime} 52^{\prime \prime}\right)$.

\section{Soil and water analyses of the selected locations}

Soil samples from both locations were collected before sowing to a depth of $0-30 \mathrm{~cm}$, where the bulk of root system is usually irrigated. In addition, the irrigation water samples were also collected. The collected soil samples were air dried, ground and sieved through $2 \mathrm{~mm}$ stainless steel sieve and stored in plastic vials for different analyses. Soil $\mathrm{pH}$ value was determined in the soil paste by using a glass electrode $\mathrm{pH}$ meter. Electrical conductivity (ECe) was determined for saturated extract by using standard conductivity bridge at $25^{\circ} \mathrm{C}$. Soluble $\mathrm{K}, \mathrm{Mg}$ and $\mathrm{Na}$, were extracted by $1 \mathrm{~N}$ ammonium acetate buffer solution adjusted at $\mathrm{pH}$ 7.0. K and $\mathrm{Na}$ concentrations were measured by flame emission (JENWAY, PFP-7, ELE Instrument Co. Ltd., UK) and Mg by Atomic-absorption spectroscopy (Analyst 200, Perkin Elmer, Inc., MA, USA). Soil physical and chemical prosperities (Table 1), and water chemical proprieties (Table 2), were assessed according to the standard methods published by Page et al. (1982).

\section{Location preparation}

Soil in both locations was prepared for cultivation by land plough and ridges construction. Compost with a rate of $10 \mathrm{t}$ $\mathrm{ha}^{-1}$ and phosphorus at rate of $120 \mathrm{~kg} \mathrm{P}_{2} \mathrm{O}_{5} \mathrm{ha}^{-1}$ were added during the final preparation of land and thoroughly mixed with the soil. Nitrogen was added as side dressing at rate of
$214 \mathrm{~kg} \mathrm{~N} \mathrm{ha}^{-1}$ in two equal doses at 30 and 60 days after sowing. Potassium was added at rate of $110 \mathrm{~kg} \mathrm{~K}_{2} \mathrm{O} \mathrm{ha}^{-1}$ at flowering stage. Seeds were sown on the second week of December, and they were harvested on the second week of April in both locations (L1 and L2) in both seasons of 2013 and 2014, respectively. About 10 - 15 seeds per hill were sown at a density of 100.000 plants per hectare. A complete randomized design with four experimental plots (replicates), each with an average area of $24.5 \mathrm{~m}^{2}$ was used. Three weeks after sowing date, plants were thinned to one plant per hill and crop practice managements were regularly carried out.

\section{Yield, chemical composition and mineral contents}

At harvesting stage, plant samples from one square meter of the central rows in each plot were randomly taken by cutting at ground level. The plant samples were then lift to air-dried for at least 4 days. The dried plant samples were threshed and winnowed by hand. Afterward, grain yield $\left(\mathrm{kg} \mathrm{ha}^{-1}\right)$ and weight of 1000 grains (g) were determined. Grain samples were dried at $65^{\circ} \mathrm{C}$ till constant weight then ground in stainless-steel mill for further analysis.

The dry weight, moisture content as well as ash contents were recorded. According to the methods described in AOAC (1995), the crude fiber was measured using Ankom Fibre Analyzer A-200 (ANKOM Technology, Macedon NY, USA). Crude fat was determined using VELP solvent extractors unit SER 148/3 (VELP Scientific, Inc., Bohemia NY, USA) using acetone as a solvent, while the total carbohydrates content was calculated by the difference.

Dried grain samples were wet digested as described by Wolf (1982). The contents of N, P, K, Ca, Fe, Mn, Zn, Na and Cu were measured. Total nitrogen were determined using microkjeldahl method and its concentration is used to calculate the crude protein contents in quinoa grains (protein $\%=$ total $\mathrm{N} \mathrm{x}$ 6.25). Phosphorus was determined by modified colorimetric method using spectrophotometer (SPECTRONIC 20D, Milton Roy Co. Ltd., USA). Potassium and sodium were measured using flame photometer method (JENWAY, PFP-7, ELE Instrument Co. Ltd., UK). In addition, $\mathrm{Ca}, \mathrm{Fe}, \mathrm{Zn}, \mathrm{Mn}$ and $\mathrm{Cu}$ were determined using Atomic absorption spectroscopy (Analyst 200, Perkin Elmer, Inc., MA, USA), as described by Chapman and Pratt (1982).

\section{Scanning Electron Microscopy/Energy Dispersive X-ray microanalysis}

Scanning Electron Microscope (SEM) and Energy dispersive $\mathrm{X}$-ray microanalysis (EDX) were carried out for seeds produced from field experiments (Prego et al., 1998; Goldstein et al., 2003). Whole and transversely cut seeds were mounted onto aluminum stubs then examined under Field Emission Scanning Electron Microscope (FE-SEM), model Quanta FEG-250 (Philips N.V., USA). Furthermore, the distribution pattern of potassium, phosphorus, magnesium and sodium within the different seed tissues was assessed semi-quantitatively by line scanning technique using FESEM linked with EDX-detector (Oxford Azteck, operating with EDS Analysis Software ver. 2.1) at an accelerating voltage of $20 \mathrm{kV}$.

\section{Statistical analysis}

All data sets were tabulated and subjected to statistical analysis using one-way-ANOVA of the SPSS software (SPSS Inc., 2002, release 16, Chicago, IL, USA). Duncan test was 
employed to compare the significant differences among mean of the treatments at 0.05 level of probability.

\section{Conclusion}

Under greenhouse conditions, the grain yield depression falls down to $50 \%$ of the control plant at salinity level of $200 \mathrm{mM}$ $\mathrm{NaCl}$ (the limits of salinity resistance). Meanwhile, the reduction of grain yield recorded $61.7 \%$ at saline field conditions (ECe $17.9 \mathrm{dSm}^{-1}$ ) compared with non-saline field conditions (ECe $1.9 \mathrm{dSm}^{-1}$ ). While the total carbohydrate and total fat contents of the seeds significantly decreased in response to salinity, the protein content was not affected. Moreover, ash and fiber contents significantly increased by about 110.8 and $15.7 \%$, respectively, in seeds obtained from saline soil compared with those from non-saline soil. Under saline soil, seed $\mathrm{Na}^{+}$content was significantly increased four folds compared to those of non-saline soil. Interestingly, most of absorbed $\mathrm{Na}^{+}$in the seeds was mainly uploaded into the pericarp, thus maintaining the interior reserving tissues with a comparatively low $\mathrm{Na}^{+}$content. Our results revealed clearly that saline soil (ECe $17.9 \mathrm{dSm}^{-1}$ ), which would be inhibitory for most if not all conventional crops, did not significantly affect the mineral contents, rather it led to increase the content of most essential elements, besides keeping of the other chemical compositions in an acceptable values of quinoa seeds. This further confirming the potential of quinoa as a promising cash crop halophyte for marginal areas in Egypt.

\section{Acknowledgements}

This research is supported by an agricultural target research project "Quinoa as a new non-traditional crop in Egypt, ID2552" funded by Science \& Technology Development Fund (STDF), Academy of Scientific Research and Technology (ASRT), Ministry of Higher Education \& Scientific Research, Egypt.

\section{References}

Abdullah Z, Khan MA, Flowers TJ (2001) Causes of sterility in seed set of rice under salinity stress. J Agron Crop Sci. 187(1):25-32

Abugoch L, Castro E, Tapia C, Anõn MC, Gajardo P, Villarroel A (2009) Stability of quinoa flour proteins (Chenopodium quinoa Willd.) during storage. Int J Food Sci Tech. 44:2013-2020.

Adolf VI, Shabala S, Andersen MN, Razzaghi F, Jacobsen SE (2012) Varietal differences of quinoa's tolerance to saline conditions. Plant Soil. 357(1-2):117-129.

Al-Aghabary K, Zhu Z, Shi QH (2004) Influence of silicon supply on chlorophyll content, chlorophyll fluorescence and antioxidative enzyme activities in tomato plants under salt stress. J Plant Nutr. 27(12):2101-2115.

AOAC (1995) Official methods of analysis of AOAC International. $16^{\text {th }}$ edition. Arlington, VA, USA.

Arnon DI, Hoagland DR (1940) Crop production in artificial solutions and in soils with special reference to factors influencing yield and absorption of inorganic nutrients. Soil Sci. 50:463-485.

Ashour NI, Serag MS, Abd El-Haleem AK, Mekki BB (1997) Forage production from three grass species under saline irrigation in Egypt. J Arid Environ. 37:299-307.
Bonales-Alatorre E, Pottosin I, Shabala L, Chen ZH, Zeng F, Jacobsen SE, Shabala S (2013) Differential activity of plasma and vacular membrane transportes contributes to genotypic differences in salinity tolerance in halophyte species, Chenopodium quinoa. Int J Mol Sci. 14:92679285.

Brazkez M, Daoud S, Harrouni MC, Tachbibi N, Brakez Z (2016) Nutritional value of Chenopodium quinoa seeds obtained from an open field culture under saline conditions. In: Khan MA, Ozturk M, Gul B, Ahmed MZ (eds), Halophytes for food security in dry lands, Academic Press, Kidlington, Oxford, UK.

Burrieza HP, Koyro HW, Tosar LM, Kobayashi K, Maldondo S (2011) High salinity induces dehydrin accumulation in Chenompodium quinoa Willd. cv. Hualhuas embryos. Plant Soil. 354:69-79.

Chapman HD, Pratt PF (1982) Methods of plant analysis, I. Methods of anaylsis for soil, plant and water. Chapman Publishers Riverside California, USA.

Choukr-Allah R, Rao NK, Hirich A, Shahid M, Alshankiti A, Toderich K, Gill S, Butt KUR (2016) Quinoa for marginal environments: toward future food and nutritional security in MENA and Central Asia regions. Front Plant Sci. 7:346.

Eid MA, Eisa SS (2010) The use of some halophytic plants to reduce $\mathrm{Zn}, \mathrm{Cu}$, and $\mathrm{Ni}$ in Soil. Aust $\mathrm{J}$ Basic Appl Sci. 4(7):1590-1596.

Eisa SS, Hussin SA, Geissler N, Koyro HW (2012) Effect of $\mathrm{NaCl}$ salinity on water relations, photosynthesis and chemical composition of quinoa (Chenopodium quinoa Willd.) as a potential cash crop halophyte. Aust J Crop Sci. 6:357-368.

Flowers TJ (2004) Improving crop salt tolerance. J Exp Bot. 55:307-319.

Francois LE (1996) Salinity effect on four sunflower hybrids, Agron J. 82:215-219.

Godfray HCJ, Beddington JR, Crute IR, Haddad L, Lawrence D, Muir JF, Pretty J, Robinson S, Thomas SM, Toulmin C (2010) Food security: The challenge of feeding 9 billion people. Sci. 327:812-818.

Goldstein JI, Newbury DE, Joy DC, Lyman CE, Echlin P, Lifshin E, Sawyer L, Michael JR (2003) Scanning electron microscopy and X-ray microanalysis. $3^{\text {rd }}$ ed., Kluwer Academic Publishers, New York, USA.

Gomez-Pando LA, Lvarez-Castro R, Eguiluz-de la Barra A (2010) Effect of salt stress on Peruvian germplasm of Chenopodium quinoa Willd. a promising crop. J Agron Crop Sci. 196:391-396.

Gonzalez JA, Gallardo M, Hilal M, Rosa M, Prado FE (2009a) Physiological responses of quinoa (Chenopodium quinoa Willd.) to drought and waterlogging stresses: dry matter partitioning. Bot Stud. 50:35-42.

Gonzalez JA, Rosa M, Pardo MF, Hilal M, Prado FE (2009b) Morphological and physiological responses of two varieties of highland species (Chenopodium quinoa Willd.) growing under near-ambient and strongly reduced solar UVB. J Photochem Photobiol. 96(2):144-151.

Gonzalez JA, Bruno M, Valoy M, Prado FE (2011) Genotypic variation of gas exchange parameters and leaf stable carbon and nitrogen isotopes in ten quinoa cultivars grown under drought. J Agron Crop Sci. 197(2):81-93.

González JA, Eisa SS, Hussin SA, Prado, FE (2015) Quinoa: an Incan crop to face global changes in agriculture In: Murphy KM, Matanguihan J (eds) Quinoa: Improvement and Sustainable Production, John Wiley \& Sons, Hoboken NJ, USA.

Hariadi Y, Marandon K, Tian Y, Jacobsen SE, Shabala S (2011) Ionic and osmotic relations in quinoa (Chenopodium 
quinoa Willd.) plant grown at various salinity levels. J Exp Bot. 62(1):185-193.

Hussin SA, Geissler N, Koyro HW (2013) Effect of NaCl salinity on Atriplex nummularia (L.) with special emphasis on carbon and nitrogen metabolism. Acta Physiol Plant. 35(4):1025-1038.

Jacobsen SE, Quispe H, Mujica A (2001) An alternative crop for saline soils in the Andes. Scientist and Farmer-Partners in Research for the $21^{\text {st }}$ Century. CIP Program Report 1999-2000, pp. 403-408.

Jacobsen SE, Mujica A, Jensen CR (2003) The resistance of quinoa (Chenopodium quinoa Willd.) to adverse abiotic factors. Food Rev Int. 19(1 and 2):99-109.

Jacobsen SE, Liu F, Jensen CR (2009) Does root sourced ABA play a role for regulation of stomata under drought in quinoa (Chenopodium quinoa Willd.). Sci Hort. 122:281287.

Kalifa Y, Perlson E, Gilad A, Konrad Z, Scolnik PA, Bar-Zvi D (2004) Over-expression of the water and salt stressregulated AsrI gene confers an increased salt tolerance. Plant Cell Environ. 27(12):1459-1468.

Karyotis Th, Iliadis C, Noulas Ch, Mitsibonas Th (2003) Preliminary research on seed production and nutrient content for certain quinoa varieties in a saline-sodic soil. J Agron Crop Sci. 189:402-408.

Khan MA, Abdullah Z (2003) Salinity-sodicity induced changes in reproductive physiology of rice (Oryza sativa) under dense soil conditions. Environ Exp Bot. 49:145-157.

Khatum S, Flowers TJ (1995) Effect of salinity on seed set in rice. Plant Cell Environ. 18:61-67.

Kinzel H (1982) Pflanzenökologie und mineralstoffwechsel. Ulmer Verlag, Stuttgart, pp 534.

Koyro HW (2003) Study of potential cash crop halophytes in a quick check system. Task Veg Sci. 38:5-17.

Koyro HW, Geissler N, Hussin SA, Huchzermeyer B (2006) Mechanisms of cash crop halophytes to maintain yield and reclaim soils in arid areas. In: Khan MA, Weber DJ (eds) Task Veg Sci 40. Ecophysiology of high salinity tolerant plants. Springer, pp. 345-366.

Koyro HW, Eisa SS (2008) Effect of salinity on composition, viability and germination of seeds of Chenopodium quinoa Willd. Plant Soil. 302:79-90.

Koyro HW, Lieth H, Eisa SS (2008) Salt tolerance of Chenopodium quinoa Willd. In Leith $\mathrm{H}$, Sucre MG, Herzog B (eds) Mangroves and halophytes: restoration and utilization, Springer, Dordrech, the Netherlands pp.133-145

Koyro HW, Khan MA, Leith H (2011) Halophytic crops: A resource for the future to reduce the water crisis. Emir $\mathbf{J}$ Food Agric. 23(1):1-16

Ladeiro B (2012) Saline agriculture in the $21^{\text {st }}$ century: Using salt contaminated resources to cope food requirements. J Bot. 1-7

Läuchli A, Grattan SR (2007) Plant growth and development under salinity stress. In: Jenks MA, Hasegawa PM, Jain SM (eds.), Advances in molecular breeding toward drought and salt tolerant crop. Springer, Dordrecht, Netherlands.

Leith H, Mochtschenko M (2002) Halophyte use in different climate IV. Cash crop halophytes for future halophytes growers. Leiden Backhuys Publishers, The Netherlands.

Marschner H (1995) Mineral nutrition of higher plants. $2^{\text {nd }}$ ed, Academic Press, London, UK.

Mishra S, Das AB (2004) Effect of short-term exposure to $\mathrm{NaCl}$ on photochemical activity and antioxidant enzymes in Bruguierapa viflora, a non-secretor mangrove. Acta Physiol Plant. 26(3):317-326.

Munns R, Tester M (2008) Mechanisms of salinity tolerance. Annu Rev Plant Biol. 59:651-681.
Page AL, Miller RH, Keeney DR (1982) Methods of soil analysis. $2^{\text {nd }}$ ed., Amer Soc Agron Soil Sci Soc Amer Inc, Madison, Wisconsin, USA.

Panuccio MR, Jacobsen SE, Akhtar SS, Musscolo A (2014) Effect of saline water on seed germination and early seedling growth of halophyte quinoa. AoB Plants. 6(47):118.

Pappier U, Pinto VF, Larumbe G, Vaamonde G (2008) Effect of processing for saponin on fungal contamination of quinoa seeds (Chenopodium quinoa Willd.). Int $\mathrm{J}$ Food Microbiol. 125(2):153-157.

Prado RE, Boero C, Gallard M, Gonzalez JA (2000) Effect of $\mathrm{NaCl}$ on germination, growth and soluble sugar content in Chenoposium quinoa Willd. seeds. Bot Bull Acad Sin. 41:27-34.

Prego I, Maldonado S, Otegui M (1998) Seed structure and localization of reserves in Chenopodium quinoa. Ann Bot. 82:481-488

Pulvento C, Riccardi M, Lavini A, Lafelice G, Macrconi E, d'Andria R (2012) Yield and quality characteristics of quinoa grown in open field under different saline and non saline irrigation regimes. J Agron Crop Sci. 198:254-263.

Reddy MP, Shab MT, Patolia JS (2008) Salva dorapersiea, a potential species for industrial oil production in semi arid saline and alkali soils. Ind Crops Prod. 28:273-278.

Repo-Carrasco R, Espinoza C, Jacobsen SE (2003) Nutritional value and use of the Andean crops quinoa (Chenopodium quinoa) and Kaniwa (Chenopodium pallidicaule). Food Rev Int. 19(1):179-189.

Risi TC, Galwey NW (1984) The Chenopodium grains of the Andes Inca Crops for modern agriculture. Adv Appl Biol. 10:145-216.

Shabala S, Hariadi Y, Jacobsen SE (2013) Genotypic difference in salinity tolerance in quinoa is determined by differential control of xylem $\mathrm{Na}^{+}$loading and stomatal density. J Plant Physiol. 17:906-914.

Shannon MC, Grieve CM (1999) Tolerance of vegetable crops to salinity. Sci Hortic. Amsterdam. 78:5-38.

Stavridou E, Hastings A, Webster RJ, Robson PRH (2016) The impact of soil salinity on the yield, composition and physiology of bioenergy grass Miscanthus $\mathrm{x}$ gigantues. GCB Bioenergy. doi: 10.1111/gebb.12351

Sultana N, Ikeda T, Itih R (1999) Effect of NaC1 salinity on photosynthesis and dry matter accumulation in developing rice grains. Environ Exp Bot. 42:211-220.

Tapia M (2000) Capitulo III: Agronomia de los cltivosandinos. Granosandinos: quinua (Chenopodium quinoa Willd.) En: Cultivosandinossubexplotadossuaporte'a la allmentacion. C. Moron (Ed). Cultivosandinos 1.0/FAO. http://www.fao.org/regional/lamerica/prior/segalim/prodali $\mathrm{m} / \mathrm{prodveg} / \mathrm{cdrom} /$ contenido/libro10.htm.

Vilche C, Gely M, Santalla E (2003) Physical properties of quinoa seeds. Biosys Eng. 86(1):59-65.

Wolf B (1982) A comprehensive system of leaf analysis and its use for diagnosing crop nutrients status. Comm Soil Sci Plant Analysis. 13:1035-1059.

Wright KH, Huber KC, Fairbanks DJ, Huber CS (2002) Isolation and characterization of Atriplex hortensis and sweet Chenopodium quinoa starches. Cereal Chem. 79(5):715-719.

Wu G, Peterson AJ, Morris CF, Murphy KM (2016) Quinoa seed quality response to sodium chloride and sodium sulfate salinity. Front Plant Sci. 7:790.

Yeilaghi H, Arzani A, Ghaderian M, Fotovat R, Feizi M, Pourdad SS (2012) Effect of salinity on seed oil content and fatty acid composition of safflower (Carthamus tinctorius L.) genotypes. Food Chem. 130:618-625. 